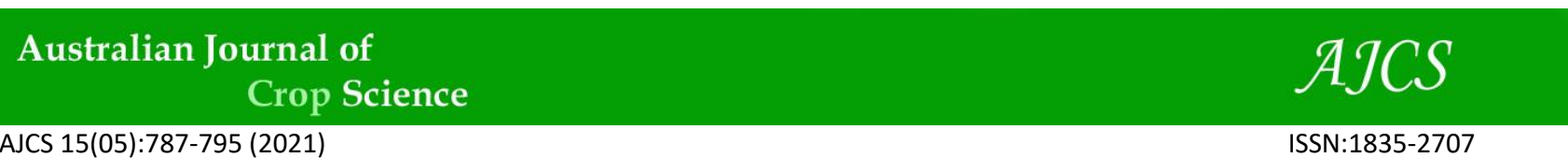

AJCS 15(05):787-795 (2021)

ISSN:1835-2707

doi: 10.21475/ajcs.21.15.05.p3206

\title{
Bacillus subtilis - capacity for enzymatic degradation, resistance to trace elements, antagonisms and siderophore production
}

\author{
Bianca de Melo Silveira dos Santos ${ }^{1}$, Maura Santos dos Reis de Andrade Silva ${ }^{1}$, Davy William Hidalgo \\ Chávez $^{2}$, Everlon Cid Rigobelo ${ }^{1}$
}

\author{
${ }^{1}$ Graduate Program in Agricultural Microbiology, Faculty of Agrarian and Veterinary Sciences, State University of \\ São Paulo (UNESP), Jaboticabal, Brazil \\ ${ }^{2}$ Graduate Program in Food Science and Technology of the Federal Rural University of Rio de Janeiro (PPGCTA- \\ UFRRJ), Seropédica, Brazil
}

\begin{abstract}
The use of microorganisms in agriculture as biofertilizers and biocontrol agents, in addition to their use in biotechnological practices, has been explored increasingly frequently over the years. Some bacteria, including Bacillus subtilis, have many capabilities related to promoting plant growth. The present study attempted to evaluate eight $B$. subtilis strains regarding their capacity for enzymatic degradation, resistance to trace elements, antagonism against phytopathogenic fungi and siderophore production. The tests were performed in plate dishes and test tubes with six repetitions for each bacterial isolate. The results showed that all isolates were able to perform enzymatic degradation to phosphatase, amylase and cellulase. Regarding resistance to trace elements, for $\mathrm{Cd}, 0.5 \mathrm{mmol} \mathrm{L}^{-1}$ was sufficient to prevent the development of strains 248, 263 and 320; for $\mathrm{Cu}$, isolate 263 obtained greater resistance; for $\mathrm{Zn}$, isolate 320 was inhibited at $2.0 \mathrm{mmol} \mathrm{L}-1$, for $\mathrm{Cr}(\mathrm{III})$, isolates 290 and 291 showed greater resistance to the metal, whereas for $\mathrm{Cr}(\mathrm{VI})$, isolates showed the same resistance pattern; and for $\mathrm{Ni}$, isolates showed the same resistance behavior. In vitro antagonism occurred for all isolates; however, the antagonism occurred at different intensities, except for isolate 291. The production of siderophores was identified for only six isolates: $287,320,309,274,263$ and 248 . These results establish a foundation for further investigations to clarify the conditions and/or characteristics required by isolates for a more effective performance, observing metabolic routes and genetic mechanisms.
\end{abstract}

Keywords: Bioremediation, Bacillus subtilis, Biotechnology, Siderophores, Antagonism.

\section{Introduction}

The capacity to promote plant growth has been exhibited by many microbes. The beneficial effects of bacteria derived from the plant rhizosphere on roots and overall plant growth have been demonstrated. These types of bacteria have been designated plant-growth-promoting rhizobacteria (PGPR). The significant beneficial effect of these rhizobacteria on plant growth is achieved by both direct and indirect mechanisms. Direct methods include the production of compounds that stimulate plant growth and ameliorate stress (Goswami et al., 2016)

Plant rhizospheres are special environments with complex plant root-soil microbe interactions (Jha et al., 2013). These complex interactions are proposed to follow root exudations, which serve to attract beneficial soil bacteria to plant roots (Zhang et al., 2017).

Bacilli are among the most investigated rhizobacterial species (Souza et al., 2015), after Pseudomonas, mostly for their biocontrol activities (Idris et al., 2007). Reports indicate that bacilli are also the most abundant in plant rhizospheres (Sivasakthi et al., 2014), constituting up to $95 \%$ of the grampositive rhizobacterial populations in plant rhizospheres (Prashar et al., 2013). According to Kumar et al. (2012a), these bacteria are efficient PGPR and capable of enhancing plant growth through the production of substances such as antibiotics and antifungal metabolites (Chowdhury et al., 2013), siderophores (Compant et al., 2005) and lytic enzymes (Nelson, 2004). Members of the Bacillus genus are particularly popular candidates for PGP because they sporulate and are easier to subject to commercial formulation (Mendis et al., 2018)

Bacillus species can form long-lived, stress-tolerant spores and secrete metabolites that stimulate plant growth and prevent pathogen infection (Radhakrishan et al., 2017).

Bacillus subtilis also plays a significant role in improving tolerance to biotic stresses. This induction of disease resistance involves the expression of specific genes and hormones such as 1-aminocyclopropane-1-carboxylate deaminase (ACC). Ethylene limits root and shoot growth and helps to maintain plant homeostasis. The degradation of the ethylene precursor (ACC) by bacterial ACC helps to relieve plant stress and maintain normal growth under stressful conditions (Glick et al., 2007).

Colonization of roots by Bacillus subtilis is beneficial to both the bacterium and the host plant. Approximately $30 \%$ of the fixed carbon produced by plants is secreted through root exudates. Colonization of the roots by bacteria provides a nutrient source, and in exchange, plants are the recipient of bacterial compounds and activities that stimulate plant growth and provide stress protection to their hosts. Bacillus subtilis forms a thin biofilm on the roots for long-term colonization of the rhizosphere. Root (Allard et al., 2016). 
However, B. subtilis isolates demonstrated variable parameters related to promoting plant growth, and within each parameter, the isolates showed different levels.

Therefore, the present study aimed to characterize and identify the enzymatic degradation capacity, resistance to trace elements, antagonism against phytopathogenic fungi and production of siderophores demonstrated by eight $B$. subtilis strains.

\section{Results}

\section{Enzyme degradation capacity}

The results for the detection of different enzymes synthesized by $B$. subtilis isolates can be seen in S1. Under the established conditions, all isolates were able to produce phosphatase (Figure S1-a), amylase (Figure S1-b), and cellulase (Figure S1-c).

The test to identify inorganic phosphate solubilization (Figure S1-a) was positive for all isolates. B. subtilis was able to solubilize phosphate by presenting a halo around the colony.

For the production of amylase (Figure S1-b), the BHB medium enriched with starch was observed to be slightly opaque, and it was possible to visualize the halo without staining, as there was formation of a translucent area close to the culture; however, for the best definition and visualization of the halo, Lugol staining was performed. All isolates were able to produce amylase.

For the production of cellulase, all isolates were able to hydrolyze the CMC substrate, showing cellulolytic activity through the presence of halos around the colony (Figure S1c).

\section{Ability to resist trace elements}

The existence of microorganisms in contaminated places or with the accumulation of trace elements is related to the resistance mechanism they present, which shows adaptation to such local conditions. When presenting resistance, these microorganisms multiply and become the majority, as they use polluting elements as a source of nutrients for their own survival. Thus, the 8 isolates identified as Bacillus subtilis were evaluated for resistance to $\mathrm{Cu}, \mathrm{Zn}, \mathrm{Cd}, \mathrm{Cr}, \mathrm{Ni}$ and $\mathrm{K}_{2} \mathrm{Cr}_{7} \mathrm{O}_{7}$ (Figure 1).

Through Figure 1, it was possible to identify that isolates presented different types of resistance against the six trace elements under study. A low cadmium concentration (0.5 $\mathrm{mmol} \mathrm{L}^{-1}$ ) (Fig 1-d) was sufficient to prevent the development of 3 isolates $-37.5 \%$ of strains analyzed (248, 263, and 320). However, for zinc and chromium concentrations, isolates showed greater resistance, with $\mathrm{IC}_{50}$ values between 1.81 and 4.30 (Fig 1 - b/e). The lower the $\mathrm{IC}_{50}$ values were, the less resistant the microorganisms were to trace elements. At concentrations greater than $2.5 \mathrm{mmol}$ $\mathrm{L}^{-1}$ for nickel, potassium dichromate, and copper ions, there was a significant decrease in the number of isolates that could be developed in vitro.

For the trace element $\mathrm{CuSO}_{4} \cdot 5 \mathrm{H}_{2} \mathrm{O}$ (Fig 1-a), isolate 263 showed greater resistance at a concentration of $3.0 \mathrm{mmol}^{-}$ 1; in contrast, isolates 297 and 309 were sensitive at concentrations above $2.0 \mathrm{mmol} \mathrm{L}^{-1}$. For $\mathrm{ZnSO}_{4} \cdot 7 \mathrm{H}_{2} \mathrm{O}$ (Fig 1-b), isolates 248, 274, 287, 290 and 309 were not affected by any concentration used; only isolate 320 showed the highest sensitivity at $2.0 \mathrm{mmol} \mathrm{L}^{-1}$ when compared to the others. When resistance to $\mathrm{K}_{2} \mathrm{Cr}_{7} \mathrm{O}_{7}$ (Fig 1-c) was analyzed, $2.5 \mathrm{mmol}$ $\mathrm{L}^{-1}$ was observed to be the concentration that most affected the development of isolates. Isolates resistant to $\mathrm{CdCl}_{2} \cdot \mathrm{H}_{2} \mathrm{O}$ (Fig 1-d) did not exceed concentrations above $1.5 \mathrm{mmol} \mathrm{L}^{-1}$, with isolates 248 and 263 being affected at $0.5 \mathrm{mmol} \mathrm{L}^{-1}$, followed by isolate 274 , which showed sensitivity at 1.0 $\mathrm{mmol} \mathrm{L}^{-1}$.

For $\mathrm{CrCl}_{3} \cdot 6 \mathrm{H}_{2} \mathrm{O}$ (Fig 1-e), isolates 290 and 291 were not affected by any of the concentrations used, since the other isolates (except 274) showed sensitivity at concentrations above $3.5 \mathrm{mmol} \mathrm{L}^{-1}$. For the trace compound $\mathrm{NiCl}_{2} \cdot 6 \mathrm{H}_{2} \mathrm{O}$ (Fig 1-f), all isolates were also observed to show the same tolerance/resistance and were affected at concentrations above $2.5 \mathrm{mmol} \mathrm{L}^{-1}$.

Through mathematical calculations using the Weibull model, it was possible to obtain values for scale (beta) and shape (alpha) parameters, in addition to obtaining the statistical significance values ( $p$-values) and the $I_{50}$ values, which allowed the identification of strains that were more sensitive to the metals used (Table 1). The values of parameters in bold indicate that they were statistically significant for the model used $(p<0.05)$. In the analysis of $\mathrm{Zn}$ and $\mathrm{Cr}$, empty columns indicate that all isolates were able to grow under all tested concentrations $\left(0.5-5.0 \mathrm{mmol} \mathrm{L}^{-1}\right)$. For trace element $\mathrm{Cd}$, empty columns indicate that isolates were sensitive at all concentrations.

\section{Correspondence analysis of resistance to trace elements}

Figure 2 corresponds to the biplot formed by the correspondence analysis that is equivalent to the principal component analysis (PCA) for nonparametric statistics, identified by the first two principal components (CP1 and CP2), observing that the sum of the variability retained in these components is $93 \%$ of the original variability, of which CP1 and CP2 each have $70.1 \%$ and $22.9 \%$, respectively. The projection on a two-dimensional plane, the biplot, seeks to specify the behavior of variables and contemplate sensitivities between isolates and trace elements. Isolates that are close to the direction of variables indicate lower sensitivity to the metal and, in the opposite direction, higher sensitivity.

The purpose of using this tool is to show the most relevant information from a data table to facilitate data presentation as new common variables called principal components. The data set was arranged in a matrix with nine lines corresponding to samples and thirty-nine columns corresponding to metals and their different concentrations.

In Figure 2, it is possible to perform a correlation with Figure 2 and to identify that isolates 320, 263 and 248 were extremely sensitive to $\mathrm{Cd}$, being at the opposite end of the biplot. In correlation with Figure 1-d, basically all isolates were observed to be sensitive to this metal, since the highest $\mathrm{IC}_{50}$ values corresponded to 1.81 . For $\mathrm{Zn}$, isolates 263,320 , and 291 were also found at the opposite end of the biplot, demonstrating that they were affected by the different concentrations of the tested metal, with $\mathrm{IC}_{50}$ values of 1.81 for isolates 320 and 3.16 for isolates 263 and 320 (Figure 1-b). Isolates 290, 287, 309, 274, and 263 showed lower sensitivities to $\mathrm{Ni}\left(I \mathrm{I}_{50} 2.65\right), \mathrm{Cr}\left(\mathrm{IC}_{50} 3.66\right.$ - 4.30), $\mathrm{K}_{2} \mathrm{Cr}_{2} \mathrm{O}_{7}\left(\mathrm{IC}_{50} 2.15-2.65\right)$ and $\mathrm{Cu}\left(\mathrm{IC}_{50} 1.81-3.16\right)$.

\section{In vitro antagonism against phytopathogenic fungi}

The antagonistic effect of these B. subtilis isolates was evaluated against four phytopathogenic fungi, Alternaria alternata, Colletotrichum gloeosporioides, Phyllosticta citricarpa, and Geotrichum citri-aurantii, in two culture media, BDA and King's B (Table 2). 
Table 1. Statistical data using the Weibull model for different concentrations of trace elements.

\begin{tabular}{|c|c|c|c|c|c|c|c|c|c|}
\hline \multirow[t]{2}{*}{ Trace elements } & \multirow[t]{2}{*}{ Parameters } & \multicolumn{8}{|c|}{ Isolates } \\
\hline & & 274 & 320 & 263 & 248 & 291 & 290 & 309 & 287 \\
\hline \multirow[t]{4}{*}{$\mathrm{CuSO}_{4} \cdot 5 \mathrm{H}_{2} \mathrm{O}$} & alfa & -28.88 & -23.60 & -34.16 & -23.60 & -28.88 & -28.88 & -35.35 & -35.35 \\
\hline & beta & 2.62 & 2.12 & 3.12 & 2.12 & 2.62 & 2.62 & 1.79 & 1.79 \\
\hline & IC50 & 2.65 & 2.15 & 3.16 & 2.15 & 2.65 & 2.65 & 1.81 & 1.81 \\
\hline & $\mathrm{R} 2$ & 0.9999 & 0.9999 & 0.9999 & 0.9999 & 0.9999 & 0.9999 & 0.9999 & 0.9999 \\
\hline \multirow[t]{4}{*}{$\mathrm{ZnSO}_{4} \cdot 7 \mathrm{H}_{2} \mathrm{O}$} & alfa & & -35.35 & -34.16 & & -34.16 & & & \\
\hline & beta & & 1.79 & 3.12 & & 3.12 & & & \\
\hline & IC50 & & 1.81 & 3.16 & & 3.16 & & & \\
\hline & $\mathrm{R} 2$ & & 0.9999 & 0.9999 & & 0.9999 & & & \\
\hline \multirow[t]{4}{*}{$\mathrm{K}_{2} \mathrm{Cr}_{7} \mathrm{O}_{7}$} & alfa & -28.88 & -23.60 & -23.60 & -23.60 & -23.60 & -23.60 & -23.60 & -23.60 \\
\hline & beta & 2.62 & 2.12 & 2.12 & 2.12 & 2.12 & 2.12 & 2.12 & 2.12 \\
\hline & IC50 & 2.65 & 2.15 & 2.15 & 2.15 & 2.15 & 2.15 & 2.15 & 2.15 \\
\hline & $\mathrm{R} 2$ & 0.9999 & 0.9999 & 0.9999 & 0.9999 & 0.9999 & 0.9999 & 0.9999 & 0.9999 \\
\hline \multirow[t]{4}{*}{$\mathrm{CdCl}_{2} \cdot \mathrm{H}_{2} \mathrm{O}$} & alfa & -7.60 & & & & -35.35 & -35.35 & -35.35 & -35.35 \\
\hline & beta & 0.60 & & & & 1.79 & 1.79 & 1.79 & 1.79 \\
\hline & IC50 & 0.63 & & & & 1.81 & 1.81 & 1.81 & 1.81 \\
\hline & $\mathrm{R} 2$ & 0.9999 & & & & 0.9999 & 0.9999 & 0.9999 & 0.9999 \\
\hline \multirow[t]{4}{*}{$\mathrm{CrCl}_{3} \cdot 6 \mathrm{H}_{2} \mathrm{O}$} & alfa & -23.60 & -39.44 & -39.44 & -39.44 & & & -39.44 & -39.44 \\
\hline & beta & 4.24 & 3.62 & 3.62 & 3.62 & & & 3.62 & 3.62 \\
\hline & IC50 & 4.30 & 3.66 & 3.66 & 3.66 & & & 3.66 & 3.66 \\
\hline & $\mathrm{R} 2$ & 0.9999 & 0.9999 & 0.9999 & 0.9999 & & & 0.9999 & 0.9999 \\
\hline \multirow[t]{4}{*}{$\mathrm{NiCl}_{2} \cdot 6 \mathrm{H}_{2} \mathrm{O}$} & alfa & -28.88 & -28.88 & -28.88 & -28.88 & -28.88 & -28.88 & -28.88 & -28.88 \\
\hline & beta & 2.62 & 2.62 & 2.62 & 2.62 & 2.62 & 2.62 & 2.62 & 2.62 \\
\hline & IC50 & 2.65 & 2.65 & 2.65 & 2.65 & 2.65 & 2.65 & 2.65 & 2.65 \\
\hline & $\mathrm{R} 2$ & 0.9999 & 0.9999 & 0.9999 & 0.9999 & 0.9999 & 0.9999 & 0.9999 & 0.9999 \\
\hline
\end{tabular}

a)

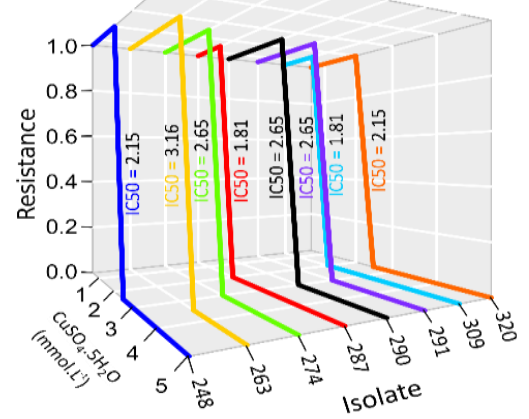

d)

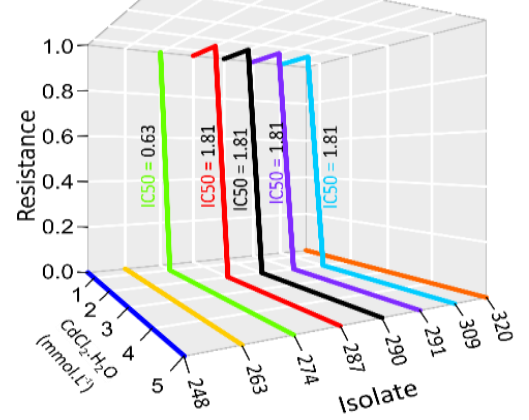

b)

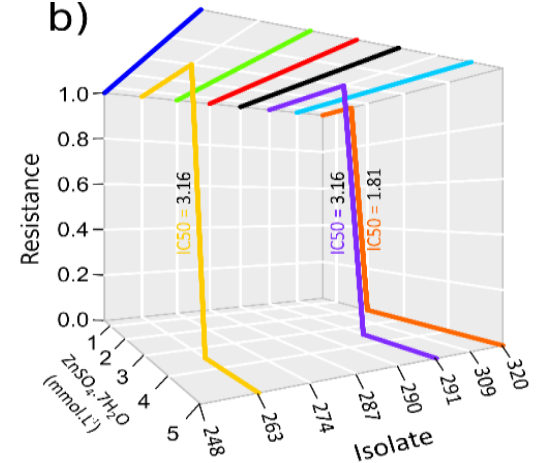

e)

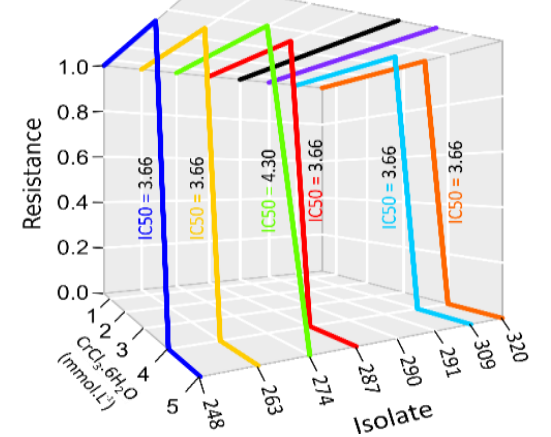

c)

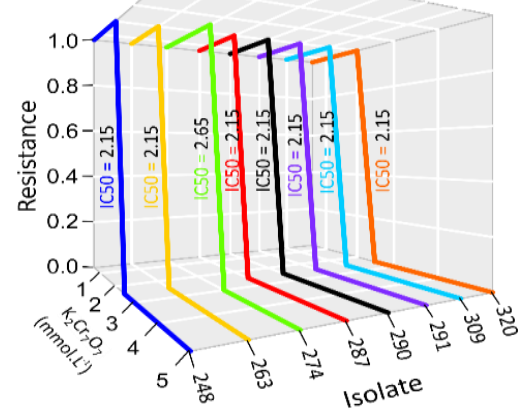

f)

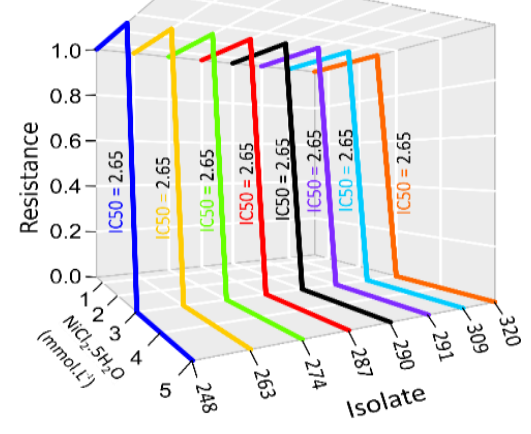

Figure 1. B. subtilis isolates resistant to concentrations of $0.5,1.0,1.5,2.0,2.5,3.0,3.5,4.0$ and $5.0 \mathrm{mmol} \mathrm{L}-1 \mathrm{Cu}, \mathrm{Zn}, \mathrm{Cd}, \mathrm{Cd}, \mathrm{Cr}, \mathrm{Ni}$ and $\mathrm{K}_{2} \mathrm{Cr}_{7} \mathrm{O}_{7} . \mathrm{IC}_{50}$ values indicate the minimum inhibitory concentration of $50 \%$. 
Table 2. Presence (+) or absence (-) of in vitro antagonism against fungi Alternaria alternata, Colletotrichum gloeosporioides, Phyllosticta citricarpa, and Geotrichum citri-aurantii in BDA and King's B culture media.

\begin{tabular}{|c|c|c|c|c|c|c|c|c|}
\hline \multirow[t]{2}{*}{ Fungus } & \multicolumn{2}{|c|}{ Alternaria alternata } & \multicolumn{2}{|c|}{$\begin{array}{l}\text { Colletotrichum } \\
\text { gloeosporioides }\end{array}$} & \multicolumn{2}{|c|}{ Phyllosticta citricarpa } & \multicolumn{2}{|c|}{$\begin{array}{l}\text { Geotrichum citri- } \\
\text { aurantii }\end{array}$} \\
\hline & \multicolumn{8}{|c|}{ Culture medium } \\
\hline Isolates & BDA & B de King & BDA & B de King & BDA & $\begin{array}{l}\text { B de } \\
\text { King }\end{array}$ & BDA & $\begin{array}{l}\text { B de } \\
\text { King }\end{array}$ \\
\hline 274 & + & + & + & + & + & ++ & + & + \\
\hline 320 & + & + & + & + & + & ++ & + & + \\
\hline 263 & + & + & + & + & + & ++ & + & + \\
\hline 248 & + & + & + & ++ & + & ++ & + & + \\
\hline 291 & + & + & + & ++ & + & ++ & + & + \\
\hline 290 & + & - & - & + & + & + & + & - \\
\hline 309 & + & + & + & + & + & ++ & + & ++ \\
\hline 287 & + & + & + & ++ & + & ++ & + & ++ \\
\hline
\end{tabular}

$+\rightarrow$ weak antagonism, with the fungus avoiding growing on the bacterial colony; $++\rightarrow$ strong antagonism, presence of halo containing the fungus; - $\rightarrow$ no antagonism, with fungal growth on the bacterial colony.

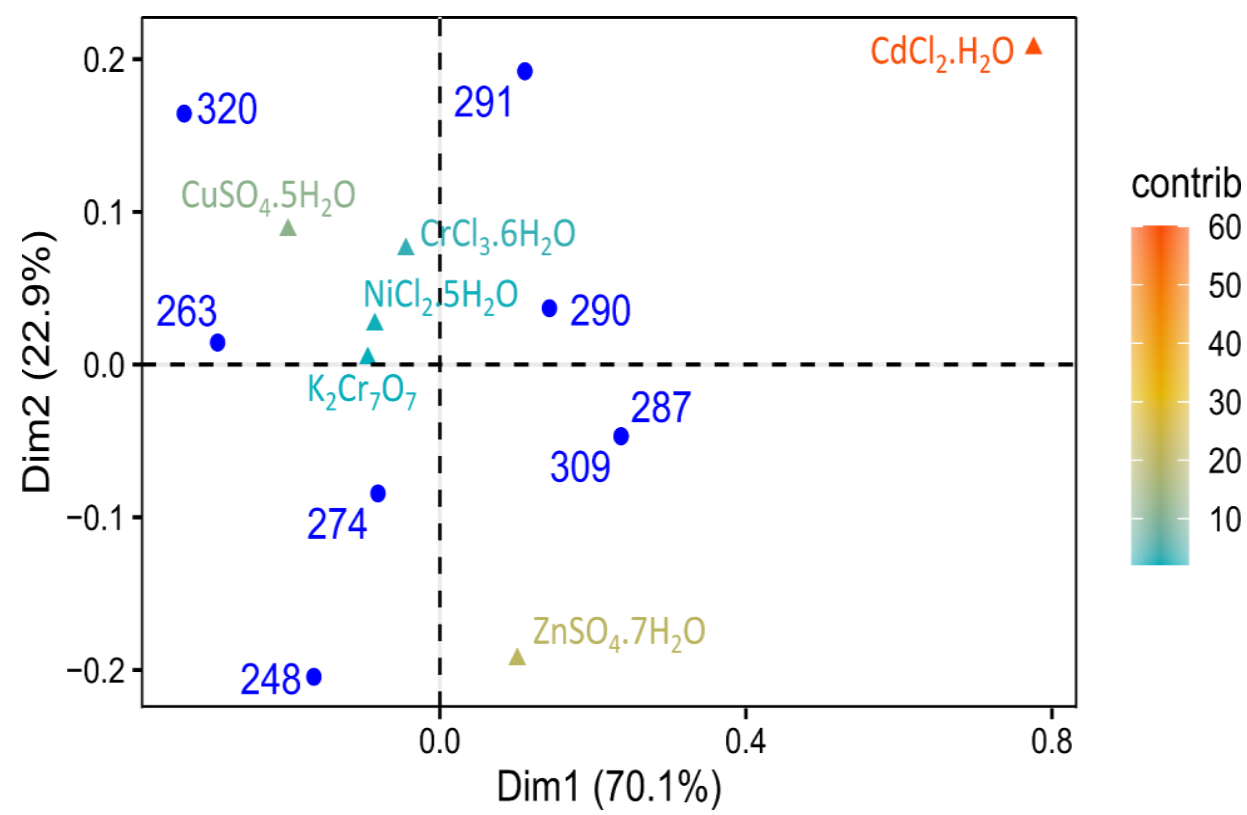

Figure 2. Spatial projection, with biplot, of principal components (PCs) regarding the sensitivity of the eight isolates to six trace elements - $\mathrm{Cu}, \mathrm{Zn}, \mathrm{Cd}, \mathrm{Cr}, \mathrm{Ni}$ and $\mathrm{K}_{2} \mathrm{Cr}_{7} \mathrm{O}_{7}$.
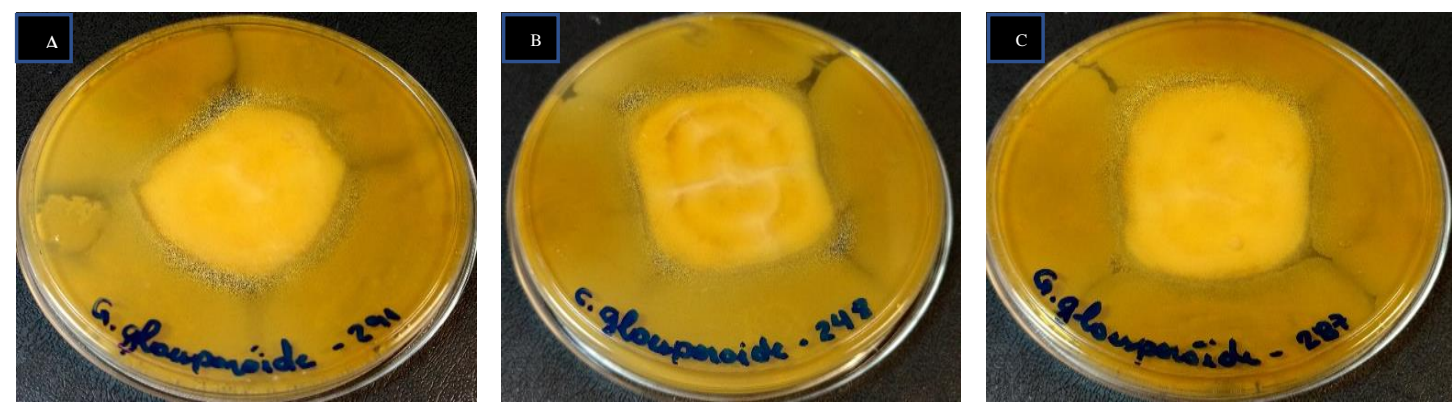

Figure 3. In vitro antagonism of the fungus Colletotrichum gloeosporioides in King's B culture medium. A - Isolate 291; B - Isolate 248; C - Isolate 287.

Seven isolates were able to show in vitro antagonism against the fungus Alternaria alternata for both culture media tested, and only isolate 290 showed no antagonism (in King's B culture medium), allowing the fungus to grow on its colony (Figure S2). In this test, the antagonism exhibited by this isolate was weak. There was no inhibition halo, and the bacterial isolates only prevented fungal growth over their colonies, suggesting possible competition for nutrients.

In the antagonism test for the fungus Colletotrichum gloeosporioides, isolates 248, 291, and 287 showed halo formation, being efficient on the fungus in King's B medium (Figure 3). For the BDA medium, seven isolates exhibited weak antagonism, showing only the growth of both 
microorganisms, and only isolate 290 in BDA medium showed no antagonism, allowing the growth of the fungus on its colony.

The fungus Phyllosticta citricarpa was inhibited by all isolates, except for isolate 290, which presented weak antagonism. Isolates 248, 263, 287, 320, 274, 309 and 291 were able to produce halos around the fungal colony (Figure S3).

The pathogen Geotrichum citri-aurantii was inhibited by only two isolates, 309 and 287, which were able to exhibit halos around the fungal colony in King's B medium (Figure S4 A/B). The remaining isolates 274, 320, 263, 248, and 291 presented weak antagonism, suggesting only nutritional competition, and isolate 291 did not present antagonism to Geotrichum citri-aurantii in King's B medium, with the fungus covering its colony (Figure $\mathrm{S} 4 \mathrm{-C}$ ).

\section{Production of siderophores}

The production of siderophores was verified by cultivating isolates in Petri dishes in an iron-deficient culture medium. The results show that of the 8 isolates of the same lineage, only 6 were able to develop under iron deficiency without inhibiting their growth (Figure S5). Through the presence of a yellow halo around the colony, it is possible to identify the positive reaction for siderophores by the CAS method.

The time for production of halos around colonies was different for each isolate, with halos between 8 and 15 days after inoculation. Isolates 290 and 291 did not develop as well as the others, with weak orange halos around their colonies.

\section{Discussion}

Through in vitro tests for the production of enzymes of biotechnological interest, with eight $B$. subtilis strains, it was possible to verify that all strains were able to solubilize inorganic phosphate and produce amylase and cellulase (Figure S1, a, b, c). In vitro tests are essential to understand and know the abilities of microorganisms (Rocha et al., 2017).

Phosphate solubilization observed in all strains indicates that such isolates provide the availability of this element for plants to promote their growth, improving their performance, according to previous studies (Lobo, 2018; Diaz 2018; Santos et al., 2020).

Plants can absorb $P$ in only two soluble ionic forms, monobasic and dibasic (Glass, 1989; Bhattacharyya and Jha \& Saraf, 2012), as this nutrient is the most limiting, after N. Phosphorus is an indispensable and essential macronutrient for plant growth and production, acting on important processes such as energy transfer and storage, photosynthesis, cell division, root growth, respiration, seed formation, as well as fruit and grain quality (Khan et al., 2009). In the soil, it is possible to find large reserves of total phosphorus; however, the amount available to plants is minimal, since most of this element is found in insoluble forms, reflecting the impossibility of plants to absorb it (Rodríguez, 1999; Freitas et al., 1997).

Plant growth-promoting bacteria of the genus Bacillus can solubilize phosphate through the production of phosphatase enzymes and the release of organic acids that are excreted in the soil (Hariprasad et al., 2009; Patiño-Torres et al., 2014). Such substances modify the organic and inorganic forms of unavailable phosphate into assimilable chemical forms, which can be stored once incorporated into the root, and when necessary, phosphorus can be taken to the upper part of the plant, being accessible for metabolic reactions of plants (Alexander, 1978; Kpomblekou-A and Tabatabai, 1994; Jha \& Saraf, 2015). Previous studies carried out with Bacillus for maize and cotton (Lobo, 2018; Diaz, 2018) presented results for efficient phosphorus solubilization, showing significant concentrations in the dry matter of roots and shoots.

All Bacillus strains were able to degrade starch. Starch is a carbohydrate synthesized by plants and is a high-molecularweight glucose polymer that can accumulate as a type of energy reserve for most higher plants and is essential for many microorganisms (Van Der Veen et al., 2000; Vieille \& Zeikus, 2001). In most plants, starch results from the storage of accumulated sugars, which can be distinguished in two forms: branched amylopectin and nonbranched amylose. Amylopectin and amylose accumulate in the form of insoluble starch grains inside amyloplasts and chloroplasts of plant cells, which can be fragmented into monosaccharides through hydrolysis reactions (Amaral et al., 2007; Evert \& Eichhorn, 2014). Studies carried out by Santos et al. (2020) found that these strains promoted the growth and development of maize plants compared to the control, which suggests a direct symbiosis with plants, as such strains were able to provide essential elements for their development and plants possibly supplied the microorganism with this carbon source in the form of energy, favoring its stability.

All Bacillus strains were able to degrade carboxymethylcellulase. Bacteria of the genus Bacillus tend to produce cellulases in the presence of $\mathrm{CMC}$, but this does not always occur when they are exposed to other substrates (Ito, 1998; Rastogi et al., 2010). The production of cellulase by endophytic microorganisms is seen as a mechanism to assist colonization of the host plant. This type of penetration is active and independent of natural openings or wounds that occur during plant growth. Bacillus penetration can trigger systemic host resistance, which is known as another mechanism of action of biological control agents (Hallmann et al., 1997).

Bacillus strains were capable of resisting the six metals tested - $\mathrm{Cu}, \mathrm{Zn}, \mathrm{Cd}, \mathrm{Cr}, \mathrm{Ni}$ and $\mathrm{K}_{2} \mathrm{Cr}_{7} \mathrm{O}_{7}$, with $\mathrm{IC}_{50}$ values above 0.5 , except for strains 248, 263 and 320 for Cd (Figure 2). Isolates that can be grown in high concentrations of trace elements depend on their resistance capacity. Resistance to such contaminants for some bacterial species could be developed by characteristics of their metabolism and genome through a variety of resistance systems mediated by plasmids, chromosomes and transposons. Although resistance to metals can occur due to prolonged exposure, which benefits the selection and multiplication of stresstolerant microorganisms caused by metals, some resistance mechanisms can occur through active transport, reduction of the sensitivity of cellular targets to metal ions, exclusion by permeable barriers and intra- and extracellular sequestration (Hutchinson and Symington, 1997; Bruins, et al., 2000; Lopes et al., 2011).

Of the eight Bacillus strains, three - 274, 290 and 291 - were resistant to $\mathrm{Cu}$ at a concentration of $2.5 \mathrm{mmol} \mathrm{L}^{-1}$ (Figure 1a); two - 248 and 320 - were resistant at a concentration of $2.0 \mathrm{mmol} \mathrm{L}^{-1}$; two - 287 and 309 - were resistant at a concentration of $1.5 \mathrm{mmol} \mathrm{L}^{-1}$; and only one -263 - showed the highest resistance at $3.0 \mathrm{mmol} \mathrm{L}^{-1}$. Copper is an essential micronutrient for prokaryotic and eukaryotic cells; however, at high concentrations, copper can cause enzymatic 
inactivation, blockage of biochemical reactions, cell lysis, interference in the process of gene translation and transcription and enzymatic inactivation (Nies, 1999; Matyar, et al., 2010; Orell, et al., 2010).

Regarding resistance presented to Zn, five strains - 248, 274, 287,290 and 309 - were able to develop at a concentration of $5.0 \mathrm{mmol} \mathrm{L}^{-1}$, two strains -263 and 290 - were resistant at a concentration of $3.0 \mathrm{mmol} \mathrm{L}^{-1}$, and only one - 309 - was resistant at a concentration of 1.5-2.5 $\mathrm{mmol} \mathrm{L}^{-1}$ (Figure 1-b). Ali et al. (2009) reported the resistance of Bacillus subtilis at a Zn concentration of $10.43 \mathrm{mM}$. Zinc is an essential element for microbial metabolism, constituting an important component for many enzymes and binding proteins, and is essential for cell performance; however, at high concentrations, zinc can become toxic, forming complexes (Bruins et al., 2000; Dopson et al., 2003).

Of the eight Bacillus strains, only six were resistant to $\mathrm{Cd}^{+2}$, presenting a drop at a concentration of $1.5 \mathrm{mmol} \mathrm{L}^{-1}$ (Figure 1-d). Ayano et al. (2014) found that a cadmium concentration of $2.0 \mathrm{mmol} \mathrm{L}^{-1}$ inhibited the growth of bacteria isolated from the soil. The presence of this element can cause irreversible damage to bacterial cells, since cadmium binds to respiratory proteins, producing reactive oxygen, leading to a decrease in cell density, reducing the growth rate and even causing death (Lee et al., 2001; Ma et al., 2009).

When analyzing resistance to $\mathrm{Cr}$, this element is known to be able to be present in several different oxidation states, with its oxidation state possibly ranging from -2 to +6 . However, only $\mathrm{Cr}(\mathrm{III})$ and $\mathrm{Cr}(\mathrm{VI})$ are stable forms in nature, with $\mathrm{Cr}(\mathrm{VI})$ typically in two forms, chromate $\left(\mathrm{CrO}_{4}^{-2}\right)$ and dichromate $\left(\mathrm{Cr}_{2} \mathrm{O}_{7}^{-2}\right)$, due to the solution $\mathrm{pH}$ (Shen and Wang, 1994; Dermou et al., 2007). When using $\mathrm{Cr}(\mathrm{III})-\mathrm{CrCl} 3 \cdot 6 \mathrm{H}_{2} \mathrm{O}$, strains 290 and 291 were observed to present higher resistance, developing at $5 \mathrm{mmol} \mathrm{L}^{-1}$. For strain 274 , the concentration that most interferes with development was $4.5 \mathrm{mmol} \mathrm{L}^{-1}$ (Figure 1-e), with the other strains interfering at a concentration of $3.5 \mathrm{mmol} \mathrm{L}^{-1}$. When strains were submitted to $\mathrm{Cr}(\mathrm{VI})-\mathrm{K}_{2} \mathrm{Cr}_{7} \mathrm{O}_{7}$, seven isolates showed the same resistance behavior to the metal, with concentration values of 2.0 mmol L-1, and only one strain (274) was able to develop at a concentration of $2.5 \mathrm{mmol} \mathrm{L}^{-1}$ (Figure 1-c). The result of such resistance occurred in a medium containing $\mathrm{Cr}$, which may refer to the use of $\mathrm{Cr}(\mathrm{III})$, a less toxic state of this metal, for the preparation of the culture medium. Although this metal presents toxicity in trivalent and hexavalent forms, some bacteria were observed to be tolerant to this element. Resistance to metals is related to the production of chelating substances that can bind and complex metals, enabling the development of such microorganisms in ecosystems where microbiota are in constant competition (Ullah et al., 2015).

To determine the resistance of all Bacillus strains to trace element $\mathrm{Ni}$, a concentration of $2.5 \mathrm{mmol} \mathrm{L}^{-1}$ (Figure 1-f) was sufficient to hinder their development. Although nickel is an important metal for the activity and constitution of metalloenzymes (Marschner, 1995; Negi et al., 2014), it can cause changes in cytosine methylation patterns causing DNA hypermethylation or hypomethylation, which can cause susceptibility of chromosomes to breakage or chromosomal instability (Kovalchuk et al., 2001). The interaction of this metal with microorganisms can lead to induced genotoxicity, where $\mathrm{Ni}$ can interact with chromatin proteins and form protein-DNA cross-links (Rossman, 1995; Anjum et al., 2015). Resistance to toxic metals is a determining factor to be pointed out in studies on the remediation of contaminated areas, which is occasionally linked to the capacity for survival, growth and bacterial development, given the high concentrations of trace elements (Kang et al., 2016).

The activity exerted by bacilli against pathogens was demonstrated for the fungi Alternaria alternata, Colletotrichum gloeosporioides, Phyllosticta citricarpa and Geotrichum citriaurantii, which can cause diseases in orange orchards (Table 2). The action of bacteria occurs through in vitro fungal growth inhibition, in which all strains were able to present antagonism, except for strain 290 , which showed no antagonism for the fungus Alternaria Alternata in King's B medium, Colletotrichum gloeosporioides in BDA medium, and Geotrichum citri-aurantii in King's B medium. Bacillus is a genus of bacteria that has antagonistic power of greater relevance, standing out for its ability to form endospores resistant to adverse circumstances and to present an abundance of antagonistic mechanisms to inhibit and reduce the defenses of phytopathogens, which allows its species to survive in specific ecological niches (Lanna Filho et al., 2010). In addition, bacteria of the genus Bacillus have the characteristic of producing hydrolytic enzymes such as cellulase, which degrade components of the cell wall of other microorganisms, giving the bacteria of the genus Bacillus the characteristic of mycoparasitism (Zago et al., 2000). Chen et al. (2008) found that Bacillus subtilis was able to produce 14 volatile antifungal compounds that inhibited the development of Botrytis cinerea, which causes gray mold in vegetables and fruits. Braga Junior et al. (2017) tested seven Bacillus subtilis strains against Fusarium subglutinans, Curvularia luneta and Bipolaris spp. and found that the isolates demonstrated potential in biological control and were effective in inhibiting mycelial growth.

The production of siderophores occurred after 8 days of inoculation, and only 6 strains were able to form an orange halo around the colony (Figure S5). Isolates 290 and 291 did not show significant growth, presenting weak halos around the colony.

Siderophores are highly electronegative secondary metabolites whose production is a characteristic that provides advantages to the survival of microorganisms in the most different environments, since the collaboration of iron in essential biological methods is a significant factor of microbial competition (Lynck et al., 2001). Siderophores are low molecular weight compounds that act in the capture of iron in the environment due to their high affinity for $\mathrm{Fe}^{+3}$, where, although $\mathrm{Fe}^{+3}$ presents low solubility, siderophores are able to act as chelators of this cation and transport it to the interior of cells (Hider and Kong, 2010). Plant growth can be promoted indirectly through the production of siderophores, as well as biological mechanisms, which can prevent the proliferation of phytopathogens around the roots due to the sequestration of rhizospheric iron (Buysens et al., 1996; Davison, 1998).

\section{Materials and Methods}

The Bacillus subtilis strains used in this work belong to the collection of microorganisms from the laboratory of Soil Microbiology, Department of Microbiology of the "Júlio de Mesquita Filho" State University of São Paulo, FCAV/UNESP Jaboticabal/SP.

\section{Enzyme Degradation Capacity}

The enzymatic degradation capacity was evaluated to identify the biotechnological potential that $B$. subtilis 
isolates present for the production of phosphatase, amylase and cellulase.

\section{Phosphatase}

Biochemical tests were performed with $B$. subtilis isolates to identify the production of phosphatase using solid NBRIP culture medium (Nautiyal et al., 1999): $20 \mathrm{~g}$ of glucose; $5 \mathrm{~g}$ of $\mathrm{Ca}_{5}(\mathrm{OH})\left(\mathrm{PO}_{4}\right)_{3} ; 5 \mathrm{~g}$ of $\mathrm{MgCl}_{2} \cdot 6 \mathrm{H}_{2} \mathrm{O} ; 0.25 \mathrm{~g}$ of $\mathrm{MgSO}_{4} \cdot 7 \mathrm{H}_{2} \mathrm{O}$; $0.2 \mathrm{~g}$ of KCl; $0.1 \mathrm{~g}$ of $\left(\mathrm{NH}_{4}\right)_{2} \mathrm{SO}_{4} ; 1.5 \%$ agar and $\mathrm{pH} 7.0$ for a total volume equal to $1 \mathrm{~L}$. Plates were incubated for 72 hours in B.O.D. The detection of the calcium phosphate solubilization capacity by bacteria was observed by the appearance of a clear halo around the colony.

\section{Amylase}

The production of amylase was evaluated using starch-agar medium: $\mathrm{K}_{2} \mathrm{HPO}(0.3 \mathrm{~g} / \mathrm{L}) ; \mathrm{MgSO}_{4} \cdot 7 \mathrm{H}_{2} \mathrm{O}(1.0 \mathrm{~g} / \mathrm{L}) ; \mathrm{NaCl}(0.5$ $\mathrm{g} / \mathrm{L}) ; \mathrm{NaNO}_{3}(1.0 \mathrm{~g} / \mathrm{L}) ; \operatorname{starch}(10 \mathrm{~g} / \mathrm{L}) ; \mathrm{pH}$ 6.9. Plates were submitted to B.O.D. at $30{ }^{\circ} \mathrm{C}$ for five days. After cultivation, plates were stained with Lugol (1\% 12: $2 \% \mathrm{KI}$ - potassium iodide) for 15 minutes, discarded and washed with $0.85 \%$ saline solution for 10 minutes, followed by a final discard. The appearance of a clear halo around the culture demonstrated the presence of amylase (Souza et al., 2008).

\section{Cellulase}

The production of cellulase was evaluated using BHB medium supplemented with $0.5 \%$ carboxy-methyl-cellulose (CMC), which was submitted to B.O.D. at $30^{\circ} \mathrm{C}$ for five days. After culture, the detection of the cellulase enzyme was evaluated by the appearance of a clear and yellowish halo around the culture after staining plates with $0.1 \%$ Congo red in water (Souza et al., 2008). All tests were performed in triplicate.

\section{Test of resistance capacity to trace elements}

The ability to resist trace elements was verified before the development of cell growth in solid medium containing different cadmium, chromium, nickel, zinc, copper and potassium dichromate concentrations. For this test, isolates were previously grown in nutrient broth $(3 \mathrm{~g}$ of meat extract; $5 \mathrm{~g}$ of meat peptone; $1 \mathrm{~g}$ of $\mathrm{NaCl}$ for $1 \mathrm{~L}, \mathrm{pH} 7.0$ ) and incubated in B.O.D. at $28^{\circ} \mathrm{C}$ for $24 \mathrm{~h}$. After this period, isolates were inoculated in plates containing nutrient agar medium ( $5 \mathrm{~g}$ of peptone; $3 \mathrm{~g}$ of yeast extract; $1 \mathrm{~g}$ of $\mathrm{NaCl} ; 9 \mathrm{~g}$ of agar; for $1 \mathrm{~L}, \mathrm{pH}$ 7.0) (Rodrigues et al., 1986) with cadmium, chromium, nickel, zinc, copper and potassium dichromate ions at the following concentrations: $0.1 ; 0.5$; 1.0; $1.5 ; 2.0 ; 2.5 ; 3.0 ; 4.0$ and $5.0 \mathrm{mmol} \mathrm{L}^{-1}$, obtained from solutions prepared by dissolving $\mathrm{CdCl}_{2} \cdot \mathrm{H}_{2} \mathrm{O}, \mathrm{CrCl}_{3} \cdot 6 \mathrm{H}_{2} \mathrm{O}$, $\mathrm{NiCl}_{2} \cdot 6 \mathrm{H}_{2} \mathrm{O}, \quad \mathrm{ZnSO} \mathrm{Z}_{4} \cdot 7 \mathrm{H}_{2} \mathrm{O}, \mathrm{CuSO}_{4} \cdot 5 \mathrm{H}_{2} \mathrm{O}$ and $\mathrm{K}_{2} \mathrm{Cr}_{7} \mathrm{O}_{7}$ in deionized water.

\section{Statistical analysis of the resistance capacity to trace elements}

The results of variables of the resistance capacity to trace elements were submitted to the survival analyses mathematical model, of sensory analyses of resistance or survival, the resistance or survival function was also used for the Weibull distribution to describe the effect of survival in different trace element concentrations through equation 1.

$$
F_{(\mathrm{t})}=1-e^{-\left(\frac{t}{\beta}\right)^{\alpha}}
$$

where $\beta$ is the scale parameter and $\alpha$ is the shape parameter.

Data were analyzed using Statistic 10 software (StatSoft, Tulsa, USA) and R software for statistical computing, version 3.2.4 (CORE_TEAM, 2017).

\section{In vitro antagonism against phytopathogenic fungi}

B. subtilis isolates were evaluated for the potential of brown spot control in citrus varieties caused by Alternaria alternata, citrus floral rot caused by Colletotrichum gloeosporioides, black citrus spot caused by Phyllosticta citricarpa, and sour rot caused by Geotrichum citriaurantii. Cultures were kindly provided by Ph.D. Prof. Kátia Cristina Kupper. The cultures belong to the collection of microorganisms of the Laboratory of Phytopathology and Biological Control of the "Sylvio Moreira" Advanced Citrus Research Center/IAC, Cordeirópolis/SP, Brazil.

A culture medium disc containing mycelial growth of the fungus was transferred to the center of Petri dishes containing King's B medium and in BDA medium in duplicate. Petri dishes were kept at $30^{\circ} \mathrm{C}$ for 48 hours. Bacteria were kept growing for $24 \mathrm{~h}$ in King's $\mathrm{B}$ medium at $30^{\circ} \mathrm{C}$ and then transferred at 4 points equidistant from each other and from the center of Petri dishes. Subsequently, Petri dishes were submitted to incubation under the same conditions again for 24 and 48 h. Antagonism could be observed by the formation of inhibition halos of the fungus by bacteria.

\section{Production of siderophores}

The production of siderophores was evaluated in solid medium MM9 (Schwyn and Neilands, 1987) supplemented with a solution containing chrome azurol $\mathrm{S}$ (CAS), $\mathrm{Fe}^{3+}$ and hexadecyl trimethyl ammonium bromide (HDTMA), as described by Louden et al. (2011).

\section{Conclusions}

The analyses carried out did not allow a better understanding of the mechanisms involved in each isolate; however, it was possible to identify strains with the capacity to degrade enzymes, showing resistance to metals, production of siderophores, and antagonistic action. These results open the way to clarify which genetic characteristics are involved in each mechanism of action so that isolates can be used as new bioinoculants in bioremediation processes and as biotechnological products.

\section{References}

Alexander M (1978) Introduction to soil microbiology. Soil Sci. 125(5):331

Allard-Massicotte R, Tessier L, Lécuyer F, Lakshmanan V, Lucier J-F, Garneau D, Caudwell L, Vlamakis H, Bais HP, Beauregard PB (2016) Bacillus subtilis early colonization of Arabidopsis thaliana roots involves multiple chemotaxis receptors. Mbio. 7(6)

Amaral Ld, Gaspar M, Costa PMF, Aidar MPM, Buckeridge MS (2007) Novo método enzimático rápido e sensível de extração e dosagem de amido em materiais vegetais. Hoehnea. 34(4):425-431

Anjum NA, Singh HP, Khan MIR, Masood A, Per TS, Negi A, Batish DR, Khan NA, Duarte AC, Pereira E (2015) Too much is bad-an appraisal of phytotoxicity of elevated plantbeneficial heavy metal ions. Environ Sci Pollut Res. 22(5):3361-3382 
Ayano $\mathrm{H}$, Miyake M, Terasawa K, Kuroda M, Soda S, Sakaguchi T, Ike M (2014) Isolation of a selenite-reducing and cadmium-resistant bacterium Pseudomonas sp. strain RB for microbial synthesis of CdSe nanoparticles. J Biosci Bioen. 117(5):576-581

Berry WL (1989) Plant Nutrition: An Introduction to Current Concepts. University of Chicago Press

Bhattacharyya PN, Jha DK (2012) Plant growth-promoting rhizobacteria (PGPR): emergence in agriculture. World J Microbiol Biotechnol. 28(4):1327-1350

Bruins MR, Kapil S, Oehme FW (2000) Microbial resistance to metals in the environment. Ecotox Environ Safe. 45(3):198207

Buysens S, Heungens K, Poppe J, Hofte M (1996) Involvement of pyochelin and pyoverdin in suppression of Pythium-induced damping-off of tomato by Pseudomonas aeruginosa 7NSK2. Applied and Environmental Microbiology. 62(3):865-871

Chen H, Xiao X, Wang J, Wu L, Zheng Z, Yu Z (2008) Antagonistic effects of volatiles generated by Bacillus subtilis on spore germination and hyphal growth of the plant pathogen, Botrytis cinerea. Biotechnol Let. 30(5):919-923

Compant S, Duffy B, Nowak J, Clement C, Barka EA (2005) Use of plant growth-promoting bacteria for biocontrol of plant diseases: Principles, mechanisms of action, and future prospects. Appl Environ Microbiol 71(9):4951-4959.

Davison J (1988) Plant beneficial bacteria. Bio/technology. 6(3):282-286

De Freitas J, Banerjee M, Germida J (1997) Phosphatesolubilizing rhizobacteria enhance the growth and yield but not phosphorus uptake of canola (Brassica napus L.). Biol Fert Soils. 24(4):358-364

Dermou E, Velissariou A, Xenos D, Vayenas D (2007) Biological removal of hexavalent chromium in trickling filters operating with different filter media types. Desal. 211(1-3):156-163

Diaz PAE, Baron NC, Rigobelo EC (2019) 'Bacillus' spp. as plant growth-promoting bacteria in cotton under greenhouse conditions. Aust J Crop Sci. 13(12):2003

Dopson M, Baker-Austin C, Koppineedi PR, Bond PL (2003) Growth in sulfidic mineral environments: metal resistance mechanisms in acidophilic microorganisms. Microbiol. 149(8):1959-1970

Glick WH, Miller CC, Cardinal LB (2007) Making a life in the field of organization science. Journal of Organizational Behavior: The International Journal of Industrial, Occupational and Organizational Psychology and Behavior .28(7):817-835

Goswami D, Thakker JN, Dhandhukia PC (2016) Portraying mechanics of plant growth promoting rhizobacteria (PGPR): a review. Cogent Food Agr. 2(1):1127500

Hallmann J, Quadt-Hallmann A, Mahaffee W, Kloepper J (1997) Bacterial endophytes in agricultural crops. Can J Microbiol. 43(10):895-914

Hariprasad P, Niranjana S (2009) Isolation and characterization of phosphate solubilizing rhizobacteria to improve plant health of tomato. Plant Soil. 316(1):13-24

Hider RC, Kong X (2010) Chemistry and biology of siderophores. Nat Prod Rep. 27(5):637-657

Hutchinson TC, Symington MS (1997) Persistence of metal stress in a forested ecosystem near Sudbury, 66 years after closure of the O'Donnell roast bed. J Geoch Expl. 58(23):323-330
Idris EE, Iglesias DJ, Talon M, Borriss R (2007) Tryptophandependent production of indole-3-acetic acid (IAA) affects level of plant growth promotion by Bacillus amyloliquefaciens FZB42. Mol Plant-Microbe Interact. 20(6):619-626

Ito S (1997) Alkaline cellulases from alkaliphilic Bacillus: enzymatic properties, genetics, and application to detergents. Extrem. 1(2):61-66

Jha CK, Saraf M (2015) Plant growth promoting rhizobacteria (PGPR): a review. J Agri Res Develop. 5(2):108-119.

Jha PN, Gupta G, Jha P, Mehrotra R (2013) Association of rhizospheric/endophytic bacteria with plants: a potential gateway to sustainable agriculture. Greener J Agr Sci. $3(2): 73-84$

Junior GMB, Junior AFC, Chagas LFB, de Carvalho Filho MR, de Oliveira Miller L, dos Santos GR (2017) Controle biológico de fitopatógenos por Bacillus subtilis in vitro. Biota Amazônia (Biote Amazonie, Biota Amazonia, Amazonian Biota). 7(3):45-51

Kang C-H, Kwon Y-J, So J-S (2016) Bioremediation of heavy metals by using bacterial mixtures. Ecol Eng. 89:64-69

Khan MS, Zaidi A, Wani PA (2007) Role of phosphatesolubilizing microorganisms in sustainable agriculture-a review. Agronomy for sustainable development 27(1):2943

Kovalchuk O, Titov V, Hohn B, Kovalchuk I (2001) A sensitive transgenic plant system to detect toxic inorganic compounds in the environment. Natur Biotechnol. 19(6):568-572

Kpomblekou-a K, Tabatabai M (1994) Effect of organic acids on release of phosphorus from phosphate rocks. Soil Sci. 158(6):442-453

Kumar A, Kumar A, Devi S, Patil S, Payal C, Negi S (2012) Isolation, screening and characterization of bacteria from Rhizospheric soils for different plant growth promotion (PGP) activities: an in vitro study. Recent Res Sci Technol. 4(1):1-5

Lanna Filho R, Ferro HM, de Pinho RSC (2010) Controle biológico mediado por Bacillus subtilis. Rev Tróp: Ciênc Agr Biol. 4(2)

Lee S-W, Glickmann E, Cooksey DA (2001) Chromosomal locus for cadmium resistance in Pseudomonas putida consisting of a cadmium-transporting ATPase and a MerR family response regulator. Appl Environ Microbiol. 67(4):1437-1444

Lobo LLB, dos Santos RM, Rigobelo EC (2019) Promotion of maize growth using endophytic bacteria under greenhouse and field conditions. Austr J Crop Sci. 13(12):2067

Lopes A, Remédios C, Deus C, Barros S (2011) Identificação da presença de bactérias resistentes a metais em solos não contaminados por poluição industrial. Rev Captar: Ciênc Amb Todos 3(2):95-103

Louden BC, Haarmann D, Lynne AM (2011) Use of blue agar CAS assay for siderophore detection. Journal of microbiology, biology education: JMBE. 12(1):51

Lynch D, O'Brien J, Welch T, Clarke P, ÓCuív P, Crosa JH, O'Connell M (2001) Genetic organization of the region encoding regulation, biosynthesis, and transport of rhizobactin 1021, a siderophore produced by Sinorhizobium meliloti. J Bacteriol. 183(8):2576-2585

Ma Z, Jacobsen FE, Giedroc DP (2009) Coordination chemistry of bacterial metal transport and sensing. Chem Rev. 109(10):4644-4681.

Marschner H (2011) Marschner's mineral nutrition of higher plants. Academic press 
Matyar F, Akkan T, Uçak Y, Eraslan B (2010) Aeromonas and Pseudomonas: antibiotic and heavy metal resistance species from Iskenderun Bay, Turkey (northeast Mediterranean Sea). Environmental Monitoring and Assessment. 167(1):309-320

Mendis HC, Thomas VP, Schwientek P, Salamzade R, Chien JT, Waidyarathne P, Kloepper J, De La Fuente L (2018) Strain-specific quantification of root colonization by plant growth promoting rhizobacteria Bacillus firmus I-1582 and Bacillus amyloliquefaciens QST713 in nonsterile soil and field conditions. PloS one. 13(2)

Nautiyal CS (1999) An efficient microbiological growth medium for screening phosphate solubilizing microorganisms. FEMS microbiology Letters. 170(1):265270

Negi A, Singh HP, Batish DR, Kohli RK (2014) Ni+ 2-inhibited radicle growth in germinating wheat seeds involves alterations in sugar metabolism. Acta Physiol Plant. 36(4):923-929

Nelson L (2004) Plant growth promoting rhizobacteria: prospects for new inoculants. Crop Manage (online). doi: 10.1094.CM-2004-0301-05RV

Nies DH (1999) Microbial heavy-metal resistance. Appl Microbiol Biotechnol. 51(6):730-750

Orell A, Navarro CA, Arancibia R, Mobarec JC, Jerez CA (2010) Life in blue: copper resistance mechanisms of bacteria and archaea used in industrial biomining of minerals. Biotechnol Adv. 28(6):839-848

Patiño-Torres CO, Sanclemente-Reyes OE (2014) Phosphatesolubilizing microorganisms (PSM): a biotechnological alternative solution for a sustainable agriculture. Entramado 10(2):288-297

Prashar P, Kapoor N, Sachdeva S (2014) Rhizosphere: its structure, bacterial diversity and significance. Rev Environ Sci Bio/Technol. 13(1):63-77
Radhakrishnan R, Hashem A, Abd-Allah EF (2017) Bacillus: A biological tool for crop improvement through biomolecular changes in adverse environments. Front in Physiol. 8:667

Raven PH, Evert RF , Eichhorn SE (2007) Biologia vegetal Biologia vegetal. $p$ 830-830

Schwyn B, Neilands J (1987) Universal chemical assay for the detection and determination of siderophores. Analit Biochem. 160(1):47-56

Shen H, Wang Y-T (1994) Biological reduction of chromium by E. coli. J Environ Eng. 120(3):560-572

Sivasakthi S, Usharani G, Saranraj P (2014) Biocontrol potentiality of plant growth promoting bacteria (PGPR)Pseudomonas fluorescens and Bacillus subtilis: A review. Afr J Agr Res. 9(16):1265-1277

Ullah A, Heng S, Munis MFH, Fahad S, Yang X (2015) Phytoremediation of heavy metals assisted by plant growth promoting (PGP) bacteria: a review. Environ Exp Bot. 117:28-40

Van der Veen BA, Uitdehaag JC, Dijkstra BW, Dijkhuizen L (2000) Engineering of cyclodextrin glycosyltransferase reaction and product specifity. Bioch Bioph Act. 1543(336):360

Vieille C, Zeikus GJ (2001) Hyperthermophilic enzymes: sources, uses, and molecular mechanisms for thermostability. Microbiol Mol Biol Rev. 65(1):1-43

Zago V (2000) Pseudomonas spp. Fluorescentes-Bactérias promotoras de crescimento de plantas e biocontroladoras de fitopatógenos em sistemas de produção agrícola. Embrapa Agrobiologia

Zhang WL, Zhang $Y$, Wang XX, Ding FS, Fu YM, Zhao JZ, Song WQ, Opiyo OJ, Zhang FM, Chen XB (2017) Siderophores in clinical isolates of Klebsiella pneumoniae promote ciprofloxacin resistance by inhibiting the oxidative stress. Biochem Biophys Res Commun. 491(3):855-861. 